\title{
Immediate early genes in social insects: a tool to identify brain regions involved in complex behaviors and molecular processes underlying neuroplasticity
}

\author{
Frank M. J. Sommerlandt ${ }^{1}$ (D) $\cdot$ Axel Brockmann ${ }^{2} \cdot$ Wolfgang Rössler $^{1} \cdot$ Johannes Spaethe $^{1}$ (D)
}

Received: 26 June 2018 / Revised: 25 September 2018 / Accepted: 15 October 2018 / Published online: 22 October 2018

(c) The Author(s) 2018

\begin{abstract}
Social insects show complex behaviors and master cognitive tasks. The underlying neuronal mechanisms, however, are in most cases only poorly understood due to challenges in monitoring brain activity in freely moving animals. Immediate early genes (IEGs) that get rapidly and transiently expressed following neuronal stimulation provide a powerful tool for detecting behavior-related neuronal activity in vertebrates. In social insects, like honey bees, and in insects in general, this approach is not yet routinely established, even though these genes are highly conserved. First studies revealed a vast potential of using IEGs as neuronal activity markers to analyze the localization, function, and plasticity of neuronal circuits underlying complex social behaviors. We summarize the current knowledge on IEGs in social insects and provide ideas for future research directions.
\end{abstract}

Keywords Activity-regulated genes $\cdot$ Mapping tool $\cdot$ Honey bee $\cdot$ Long-term memory formation $\cdot \operatorname{egr}-1 \cdot \mathrm{c}$-jun

\section{Introduction: complex behaviors with miniature brains}

Social insects like termites, ants, wasps, and bees build large colonies ranging from dozens to hundreds of thousands of individuals with overlapping generations and division of labor [1]. The multiplicity of tasks a colony is faced with is not coordinated by a centralized control system, but is rather exercised via self-organisation. Single individuals make decisions based on locally available information and interact with nestmates to produce a highly structured collective behavior [2,3]. Even though their brains are rather small and comprise a neuronal network of relatively low complexity, social insects show sophisticated capabilities in terms of communication, navigation, and cognitive tasks. Paper wasps (Polistes fuscatus), for example, identify and learn

Frank M. J. Sommerlandt

frank.sommerlandt@uni-wuerzburg.de

1 Behavioral Physiology and Sociobiology (Zoology II), Biozentrum, University of Würzburg, Am Hubland, 97074 Würzburg, Germany

2 National Centre for Biological Sciences, Tata Institute of Fundamental Research, Bellary Road, Bangalore 560065, India individual faces of nestmates [4], Cataglyphis desert ants show complex navigational behaviors [5], and leaf-cutting ants (Acromyrmex ambiguus) learn to avoid fungus-noxious plants [6]. Moreover, social bees are capable of cognitive behaviors almost comparable to vertebrates [7-12]. Bumble bees, for example, show observational learning and cultural transmission of complex behaviors [13, 14], and honey bees are capable of time and place learning, communication of navigational information via dancing behavior [15-17], counting [18-20], and complex non-elemental forms of learning [21-23]. The richness in complex behaviors and the extensive collective interactions provide valuable opportunities to study underlying neuronal circuits, their plasticity, and processes involving memory formation (Table 1) and sets social insects apart from well-established genetic insect model organisms, such as Drosophila, or more simple invertebrate models like Caenorhabditis.

In combination with behavioral assays, several tools, including live (calcium) imaging, as well as pharmacological, electrophysiological, genetic, and histological approaches, have been developed to search for a memory trace in social insects. Studies on the processes of memory formation showed that brain plasticity is reflected in changes in the firing rate of neurons, alterations in their molecular and epigenetic profile, and in reorganization of the synaptic 
Table 1 Selected social insect models and examples of complex behaviors that show potential to study underlying neuronal circuits

\begin{tabular}{lll}
\hline Social insect model organism & Behavior of interest & References \\
\hline $\begin{array}{l}\text { Termites } \\
\text { Macrotermes natalensis }\end{array}$ & Vibrational communication & Hager and Kirchner [24] \\
Ants & Navigation & \\
Cataglyphis spec. & Chemical communication & Wehner [5] \\
Ooceraea biroi & Social stress and reproduction & Trible et al. [25] \\
Harpegnathos saltator & Caste-specific polyethism & Yan et al. [26] \\
Camponotus floridanus & & Zube and Rössler [27], \\
Wasps & & Bonasio et al. [28] \\
Polistes fuscatus & Individual face recognition & \\
Bees & & Tibbetts [29] \\
Bombus terrestris & Color learning & \\
& Social learning/cultural transmission & Lichtenstein et al. [30] \\
Bombus impatiens & Route learning (traplining) & Saleh and Chittka [31] \\
& Decision making & Riveros and Gronenberg [32] \\
Apis mellifera & Dance communication & von Frisch [17] \\
& Time-place memory & Koltermann [16] \\
& Age-related polyethism & Withers et al. [33] \\
Apis florea & Associative learning and memory & Giurfa [21] \\
\hline
\end{tabular}

network [6, 36-42]. Particularly, the latter can be considered as the neuronal substrate of long-term memories (LTM) and behavioral plasticity [43]. However, the mechanisms providing the important link between transient changes of physiological properties of individual neurons and long-lasting structural reorganization or re-wiring of brain circuits are largely unexplored. A noted element of this transition process is the activation of a genomic cascade, which is precisely tuned and includes the expression of genes involved in neuronal physiology [44-46]. This leads, for example, to changes in the storage and mobilization of synaptic neurotransmitter-releasing vesicles and cell adhesion molecules (CAMs), which are essential for neuronal circuit formation (for a comprehensive review on molecular mechanisms involved in synaptic plasticity see Ho et al. [47]).

A unique group of genes that is expressed in the first transcriptional wave after neuronal activation are the immediate early genes (IEG). IEGs largely encode for transcription factors that orchestrate cellular homeostasis and neuronal plasticity. In vertebrates, IEGs are known to respond to neuronal stimulation in a rapid and transient fashion without the need of de novo protein synthesis [48-50]. Due to their transient expression that can peak within tens of minutes after stimulation, IEGs can be used as molecular markers in the search for neuronal circuits that contribute to the transition from short-term neuronal activation to long-lasting structural changes at the synaptic and neuronal network level. In social insects, this approach has not yet been established for routine use, although it would allow the study of elaborate behaviors in freely moving animals in the social context and under natural conditions (Fig. 1) [51-54]. Monitoring behavior-related IEG expression, therefore, is a very promising tool to access brain functions related to social behavior, sensory exposure and learning. It bears the potential to provide a highly attractive extension to already established neurobiological methods, like electrophysiological recordings, calcium imaging, and immunohistological approaches to analyze protein expression profiles (Table 2). A particular benefit of IEG expression analyses is that entire brains can be screened for neuronal activity, whereas other methods require a certain degree of prior knowledge on neuron populations and neuronal circuits that might be involved in the response to the applied stimulation paradigm. Therefore, the analysis of IEG activation may be particularly beneficial in identifying the brain regions or even neurons involved in complex behavioral processes like individual decision making, behavioral transitions, navigation, cognition, and advanced social communication.

With the present review, we aim to provide an overview of the current knowledge on the use of IEGs as neuronal activity markers in social insects, particularly in the honey bee, and to discuss potential perspectives for a broader implementation in social insects. 


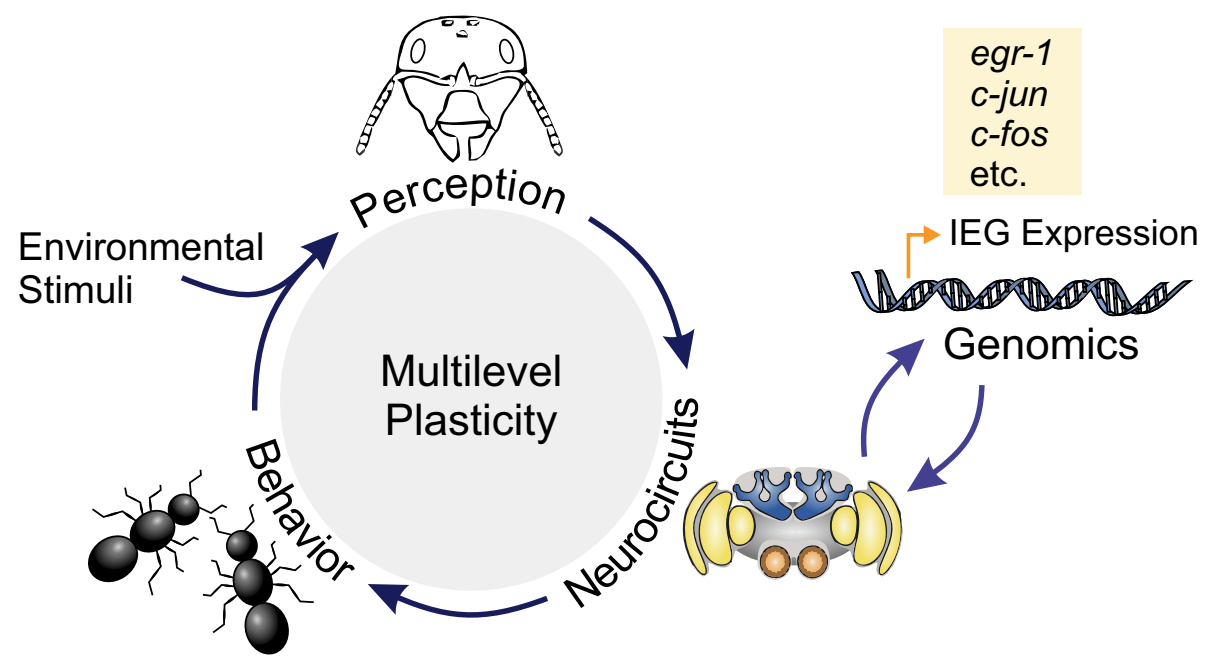

Fig. 1 Social insects show extensive collective interactions and a striking plasticity in their behaviors. Stimuli from the environment and from interactions with other individuals are integrated and processed within neurocircuits by each colony member. Sensory exposure and learning activate a genomic response cascade in neurons that leads to changes in the structure and/or physiology of the neurocir- cuits. The first transcriptional wave after neuronal activation includes the expression of immediate early genes (IEG), which orchestrate plasticity at the neuronal, behavioral, and perceptual level. Their central role in controlling mechanisms of plasticity and the transient nature of their translation-independent expression makes IEGs promising markers for activated neuronal circuits

Table 2 Comparison of advantages and limitations of different approaches for measuring neuronal activation and plasticity

\begin{tabular}{|c|c|c|c|}
\hline & $\begin{array}{l}\text { Genomic tools: } \\
\text { immediate early } \\
\text { genes }\end{array}$ & $\begin{array}{l}\text { Electrophysiology/live (calcium) } \\
\text { imaging }\end{array}$ & $\begin{array}{l}\text { Circuit analyses/neuroanatomy: neu- } \\
\text { ronal/synaptic connectivity }\end{array}$ \\
\hline $\begin{array}{l}\text { Investigating complex behaviors in } \\
\text { freely moving animals }\end{array}$ & Yes & $\begin{array}{l}\text { Limited (partially using implanted } \\
\text { electrodes/objectives) }\end{array}$ & Yes \\
\hline $\begin{array}{l}\text { Investigating Pavlovian conditioning in } \\
\text { harnessed animals }\end{array}$ & Yes & Yes & Yes \\
\hline Accessing the brain in vivo & No & Yes & Very limited \\
\hline Temporal resolution & Snapshot & Live image & Snapshot \\
\hline $\begin{array}{l}\text { Screening the complete brain for neu- } \\
\text { ronal activity }\end{array}$ & Yes & No & $\begin{array}{l}\text { Limited (requires quantitative screening } \\
\text { for changes in synaptic circuits/neuro- } \\
\text { pil volumes) }\end{array}$ \\
\hline
\end{tabular}

\section{Molecular mechanisms of neuronal plasticity}

Social insect brains undergo plastic changes in the course of ontogenetic development and in response to sensory exposure, (pheromone) communication, as well as learning and memory processes. This is reflected in a modified neuropil structure, synaptic connectivity, firing properties of single neurons, and gene expression [46, 55-59]. In the context of memory formation, different phases can be distinguished that contribute to neuronal plasticity based on underlying molecular processes (Fig. 2). The first cellular responses to stimulation occur within seconds to minutes and include the activation of voltage-dependent $\mathrm{Ca}^{2+}$ channels or membrane receptors that respond to extracellular signals such as neurotransmitters and growth factors. This activation triggers a series of intracellular second messenger pathways that include phosphatases and protein kinases, e.g., protein kinase A (PKA) and $\mathrm{Ca}^{2+} /$ calmodulin-dependent protein kinase II (CaMKII). Kinases then modify ion channels and constitutive transcription factors (transcription factors that do not necessarily require an activation but are rather permanently expressed) to orchestrate delayed neuronal responses [60-64].

Delayed responses last between hours and days and may result in permanent changes in neuronal properties and rearrangements of synaptic networks. On the molecular level, activation of constitutive transcription factors, e.g., the cAMP response element binding protein (CREB), leads to the expression of IEGs. This process constitutes the "first 
Fig. 2 Intracellular activation cascade of immediate early genes (IEGs; left column) and examples of involved molecules and molecule classes (right column). Extracellular signals activate via membrane receptors and channels a series of intracellular biochemical pathways. Kinases then mediate the activation of constitutively expressed transcription factors that initiate the expression of IEGs. Protein products of IEGs can act either as inducible transcription factors to orchestrate the expression of downstream genes, or as direct effector proteins with implications in cell physiology and signaling

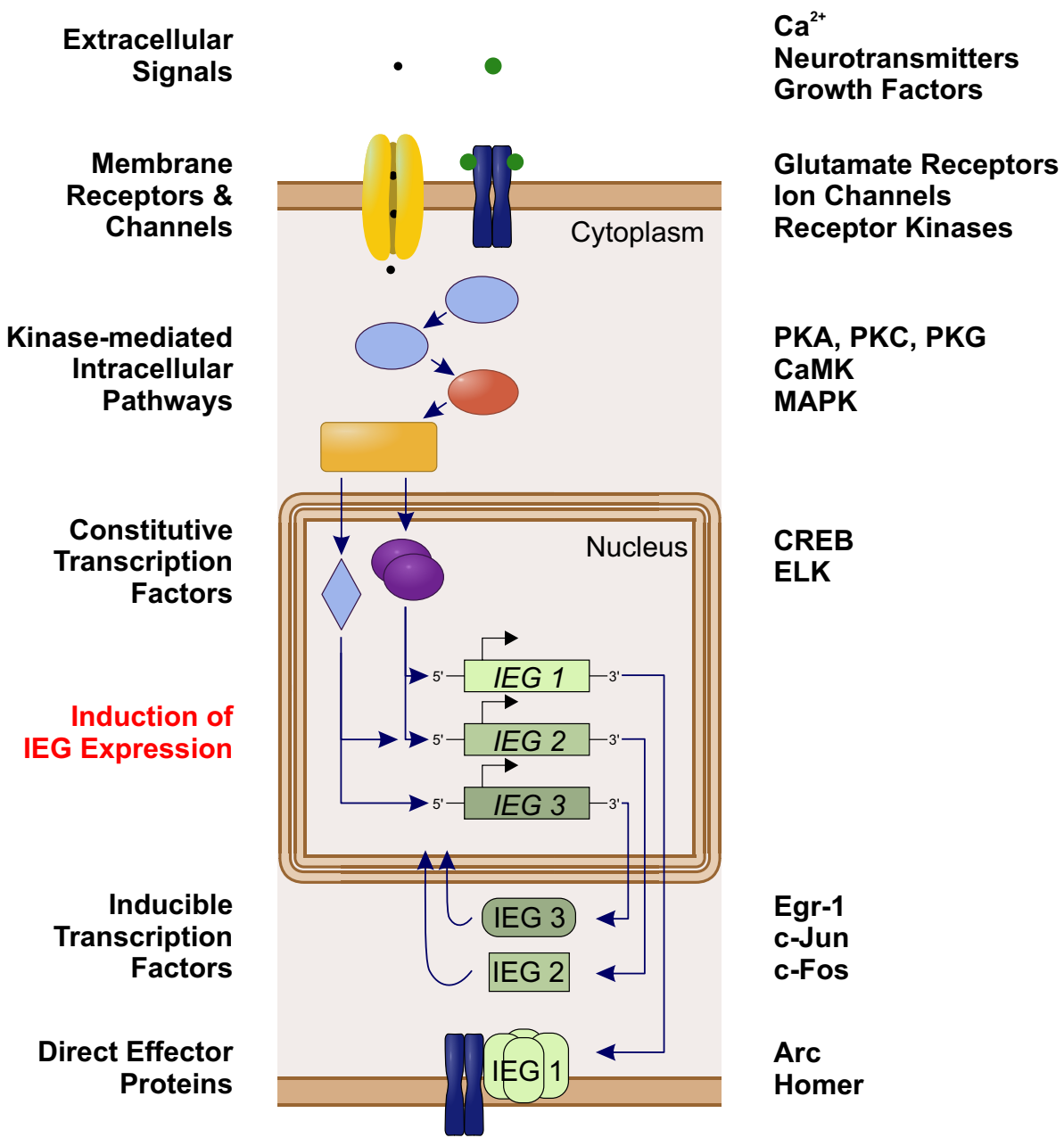

genomic response" to stimulation [44, 48, 49]. In analogy to the classical electrophysiological action potential (eAP), this "genomic action potential" (gAP; terminology introduced by Clayton [48]) represents a neuronal integration process which involves regulation of nuclear gene expression instead of membrane-associated ion channels. In contrast to the immediate synaptic transmission initiated by the eAP, the gAP regulates slower acting functional and structural modulations of the synaptic network via a pulse of increased transcription of IEGs. Activation of IEGs represents the first wave of gene transcription in response to neuronal stimulation and their expression is a prerequisite for transcriptiondependent long-term neuronal plasticity. The expression of IEGs also occurs in the presence of protein synthesis inhibitors [65-67] and each IEG responds in a characteristic manner in distinct brain regions to different types or qualities of stimulation [68]. In the absence of sensory stimulation, most IEGs are expressed at low levels, with only few exceptions [69].

Protein products of IEGs are involved in a multitude of cellular processes with diverse functions that are important in the reorganization of neuronal networks [49]. In general, two classes of IEGs can be distinguished, based on the functional role of the encoded products. The first class encodes for proteins with direct implications in cell structure and signal transduction. These IEGs are directly involved in processes such as receptor modulation, vesicle storage, or synaptic trafficking and are, therefore, called direct effectors (e.g., arc and homerla). The second class, comprising most of the commonly studied IEGs, encodes for inducible transcription factors (e.g., egr-1,c-jun, $c$-fos) which regulate the expression of downstream late-response genes involved in neuronal physiology [48, 66, 69] (Fig. 2). In both cases, transient cellular stimulation gets converted into long-term changes via the activation of a molecular response cascade.

The rapid and transient nature of their induction makes IEGs ideal markers for neuronal activation and their study offers two benefits: on the one hand, it helps understanding the molecular processes leading to modifications in synaptic functioning. On the other hand, as their expression indicates sites of neuronal activation, analyses of IEG activation patterns may provide important insights into the functional construction of the brain. In this way, the spatial distribution and temporal succession of activated neuronal circuits that are 
involved in the formation and storage of memories can be localized and analyzed.

\section{IEGs in studies of complex behaviors in vertebrates}

Eukaryotic IEGs were first described in vertebrates, for which they are now routinely used in functional mapping studies to monitor neuronal activation $[65,66]$. For most IEGs, peak mRNA levels are detectable around 30-60 min after stimulation onset and highest protein levels occur between 60 and $120 \mathrm{~min}$ after stimulation [70-73]. IEG induction in neurons was first demonstrated in response to seizures [74]. Since then, a vast number of studies reported functional links between the induction of IEG expression and social stimuli or complex behaviors, and perceptual stimulations associated with memory formation (reviewed in Refs. [48, 51, 65]). For example, IEG activation occurs in the hippocampus of rodents after visual, olfactory and spatial learning, and in the cortex when exploring novel environments [72, 75, 76]. In songbirds, IEG expression in the brain is induced when individuals are exposed to a novel conspecific song for the first time. After a song and its context became familiar by repetition, that particular song no longer induced the genomic response [70, 71, 77]. In addition, stimulus-enriched environments and drugs of abuse are known to activate IEG responses in specific brain parts $[78,79]$. Dysregulated IEG expression was linked to the pathophysiology of human neurodegenerative disorders such as Alzheimer's dementia and amyotrophic lateral sclerosis [80, 81], demonstrating their central role in orchestrating neuronal plasticity.

Besides investigating the function of IEGs within neuronal systems, IEGs were also used to monitor activation of neuron populations in co-expression experiments. The simultaneous detection of activity-regulated IEGs and cell markers such as neurotransmitters and receptors helped to identify neuron populations involved in complex vertebrate behaviors, such as mating and aggression [82] or social stress [83].

\section{The honey bee: insect model for monitoring IEG expression}

To shed light on the molecular and neuronal processes involved in complex learning and memory formation in a social context, the honey bee became an important and fruitful insect model system (reviewed in Refs. [42, 64, 84, 85]). Accelerated by the sequencing of the honey bee genome, molecular tools have been developed to study intracellular pathways in neurons and to determine the role of behaviorally relevant genes $[86,87]$.

So far, IEG expression patterns in honey bees were rarely analyzed at the protein level (to our knowledge, only one study analyzed IEG protein levels in the context of ontogenetic development; [88]), whereas most studies analyzed mRNA levels using RT-qPCR and in situ hybridization, respectively (Table 3). Activation of IEGs or genes regulated by them were compared between different pupal and adult stages $[89,90]$, and between individuals performing different tasks like nursing the brood, dancing to communicate a novel food source to nestmates, and foraging for nectar or pollen [91, 92]. Behavioral approaches aiming to stimulate IEG expression in honey bees included more general stimulation like seizures induced by awakening from anesthesia [92-95], exposure to light [96] or plant and pheromonal odors [96-98], and sucrose feeding (food reward stimulation; [99]). In addition, more specific behaviors were correlated with IEG expression, for example, feeding of sucrose or pollen of different qualities [100], as well as different aspects of orientation flights $[92,95,101]$ and foraging activity $[102,103]$.

\section{IEG candidates in honey bees: putative functions and pathways}

Studies in honey bees focused on five candidate IEGs. Four of these genes (egr-1, c-fos, $\mathrm{Hr} 38$, and c-jun) have well studied orthologs in vertebrates and encode for regulators of gene transcription. Among metazoans, these transcription factors show a high degree of conservation in the structure of their functional domains and, presumably, in involved upstream and downstream regulatory networks [89, 94, 104-107]. However, in addition to the above-mentioned transcription factors, one candidate IEG in honey bees encodes for a non-coding RNA called kakusei that might be specific to honey bees [93]. We discuss the candidate genes in more detail below.

\section{egr (zif-268, zenk, stripe, ngfi-a, krox-24; Fig. 3a)}

One of the best studied IEGs both in vertebrates and in the invertebrate Aplysia is egr-1 [108, 109]. This gene encodes a transcription factor belonging to the early growth response (Egr) protein family. The family comprises four members (Egr-1 to Egr-4) that are expressed in various isoforms [68]. A common structural feature of all members is a highly conserved DNA-binding domain comprising three tandem $\mathrm{Cys}_{2} \mathrm{His}_{2}$ zinc finger motifs, that target a GC-rich sequence of nine consecutive nucleotides (5'-GCG C/GGG GCG-3'), termed Egr-binding sequence (EBS; [68, 110-112]). EBS can be found in the promotors of several genes involved in 
Table 3 Main candidate IEGs investigated in honey bees

\begin{tabular}{|c|c|c|c|c|}
\hline Gene & Stimulant & Effector sites & Method & References \\
\hline \multirow{7}{*}{$\begin{array}{l}\text { Amegr }(\text { Egr-1, zenk, } \\
\text { zif/268, Krox-24, } \\
\text { Stripe })\end{array}$} & Environmental novelty & $\mathrm{MB} \uparrow$ & $\begin{array}{l}\text { mRNA: in situ hybridiza- } \\
\text { tion, RT-qPCR }\end{array}$ & Lutz and Robinson [101] \\
\hline & Seizure induction & $\mathrm{AL} \uparrow, \mathrm{OL} \uparrow, \mathrm{MB} \uparrow$ & $\begin{array}{l}\text { mRNA: in situ hybridiza- } \\
\text { tion, RT-qPCR }\end{array}$ & Ugajin et al. [94] \\
\hline & $\begin{array}{l}\text { Ontogenetic development: } \\
\text { early to mid pupal stage }\end{array}$ & $\mathrm{OL} \uparrow$ & $\begin{array}{l}\text { mRNA: in situ hybridiza- } \\
\text { tion, RT-qPCR (isoform- } \\
\text { specific) }\end{array}$ & Ugajin et al. [89] \\
\hline & IPA or light & No effect & mRNA: RT-qPCR & Sommerlandt et al. [96] \\
\hline & Foraging & Entire brain $\uparrow$ & mRNA: RT-qPCR & Singh et al. [102] \\
\hline & Time-dependent foraging & $\mathrm{AL} \uparrow, \mathrm{OL} \uparrow, \mathrm{KC} \uparrow$ & $\begin{array}{l}\text { mRNA: in situ hybridiza- } \\
\text { tion, RT-qPCR }\end{array}$ & Shah et al. [103] \\
\hline & Nurse-forager-transition & Entire head & $\begin{array}{l}\text { CAGEscan (Cap Analysis } \\
\text { of Gene Expression: pro- } \\
\text { motor region characteriza- } \\
\text { tion of activated genes) }\end{array}$ & Khamis et al. [91] \\
\hline \multirow[t]{5}{*}{ Amjra (c-jun) } & IPA & $\mathrm{AL} \uparrow$ & mRNA: RT-qPCR & Alaux and Robinson [97] \\
\hline & IPA & AL (inconsistent effects) & mRNA: RT-qPCR & Alaux et al. [98] \\
\hline & Sucrose feeding & $\begin{array}{l}\mathrm{AMMC} \uparrow, \mathrm{MB} \uparrow, \mathrm{LP} \uparrow, \\
\mathrm{GNGl} \uparrow, \mathrm{OL} \uparrow\end{array}$ & $\begin{array}{l}\text { mRNA: in situ hybridiza- } \\
\text { tion, } \\
\text { RT-qPCR }\end{array}$ & McNeill and Robinson [99] \\
\hline & $\begin{array}{l}\text { (a) Food type } \\
\text { (b) Food value }\end{array}$ & $\begin{array}{l}\text { (a) LP, AL, OL, MB } \\
\text { (b) AMMC, AL, OL, MB, } \\
\text { GNGl }\end{array}$ & $\begin{array}{l}\text { mRNA: in situ hybridiza- } \\
\text { tion }\end{array}$ & McNeill et al. [100] \\
\hline & IPA or light & $\mathrm{AL} \uparrow, \mathrm{OL} \uparrow, \mathrm{MB} \uparrow$ & mRNA: RT-qPCR & Sommerlandt et al. [96] \\
\hline \multirow[t]{4}{*}{ c-Fos (kayak) } & $\begin{array}{l}\text { Ontogenetic development: } \\
\text { embryonic, nymphal and } \\
\text { adult stage }\end{array}$ & $\mathrm{AL}, \mathrm{MB}$ & $\begin{array}{l}\text { Protein: immunohistochem- } \\
\text { istry, immunocytochemis- } \\
\text { try, immunoblotting }\end{array}$ & Fonta et al. [88] \\
\hline & Drone development & Mucus gland $\uparrow$ & $\begin{array}{l}\text { mRNA: RT-qPCR; cDNA } \\
\text { Representational Differ- } \\
\text { ence Analysis (RDA) }\end{array}$ & Colonello-Frattini et al. [143] \\
\hline & Bacterial infection & Fat body $\uparrow$, oenocytes $\uparrow$ & $\begin{array}{l}\text { mRNA: RT-qPCR; whole } \\
\text { genome microarray }\end{array}$ & Richard et al. [142] \\
\hline & Exposure to xenobiotics & Not specified & mRNA: RT-qPCR & Cizelj et al. [90] \\
\hline \multirow[t]{2}{*}{$h r 38(N r 4 a)$} & Caste and division of labor & $\mathrm{MB} \uparrow$ & $\begin{array}{l}\text { mRNA: in situ hybridiza- } \\
\text { tion, RT-qPCR }\end{array}$ & Yamazaki et al. [145] \\
\hline & Foraging & Entire brain $\uparrow$ & mRNA: RT-qPCR & Singh et al. [102] \\
\hline \multirow[t]{4}{*}{ kakusei } & $\begin{array}{l}\text { Seizure induction, dancer } \\
\text { vs. forager vs. nurse, } \\
\text { reorientation }\end{array}$ & $\mathrm{sKC} \uparrow, \mathrm{OL} \uparrow, \mathrm{AL} \uparrow$ & $\begin{array}{l}\text { mRNA: in situ hybridiza- } \\
\text { tion, RT-qPCR }\end{array}$ & Kiya et al. [92] \\
\hline & Seizure induction & $\mathrm{OL}, \mathrm{MB}, \mathrm{DL} \uparrow$ & $\begin{array}{l}\text { mRNA: in situ hybridiza- } \\
\text { tion, RT-PCR }\end{array}$ & Kiya et al. [93] \\
\hline & $\begin{array}{l}\text { (a) Seizure induction and } \\
\text { thermal stimulation } \\
\text { (b) IPA induction }\end{array}$ & $\begin{array}{l}\text { (a) } \mathrm{KC} \uparrow \\
\text { (b) No effect }\end{array}$ & $\begin{array}{l}\text { mRNA: in situ hybridiza- } \\
\text { tion, RT-qPCR }\end{array}$ & Ugajin et al. [146] \\
\hline & $\begin{array}{l}\text { Seizure induction, foraging, } \\
\text { reorientation, light }\end{array}$ & $\begin{array}{l}\mathrm{OL} \uparrow \\
\mathrm{AL} \text { (no effect) }\end{array}$ & $\begin{array}{l}\text { mRNA: double-in situ } \\
\text { hybridization, RT-qPCR }\end{array}$ & Kiya and Kubo [147] \\
\hline
\end{tabular}

$\uparrow$ upregulation, $A L$ antennal lobes, $A M M C$ antennal mechanosensory and motor center, $D L$ dorsal lobe, $G N G l$ lateral gnathal ganglia (formerly termed as lateral suboesophageal ganglion), IPA isopentyl acetate, $K C$ Kenyon cells, $L P$ lateral protocerebrum, $M B$ mushroom bodies, $O L$ optic lobes, $s K C$ small KC

the ecdysteroid-signaling pathway [91] and nerve cell functioning, including genes encoding synapsin I and II [113, 114], and acetylcholinesterase [115]. In addition to motifs responsive for CREB and Elk-1 transcription factors [116],
Egr genes also contain the EBS motif, resulting in a negative feedback loop [117]. All Egr protein members target the same DNA consensus sequence, yet their activity is regulated by interactions of a variable peptide sequence outside 


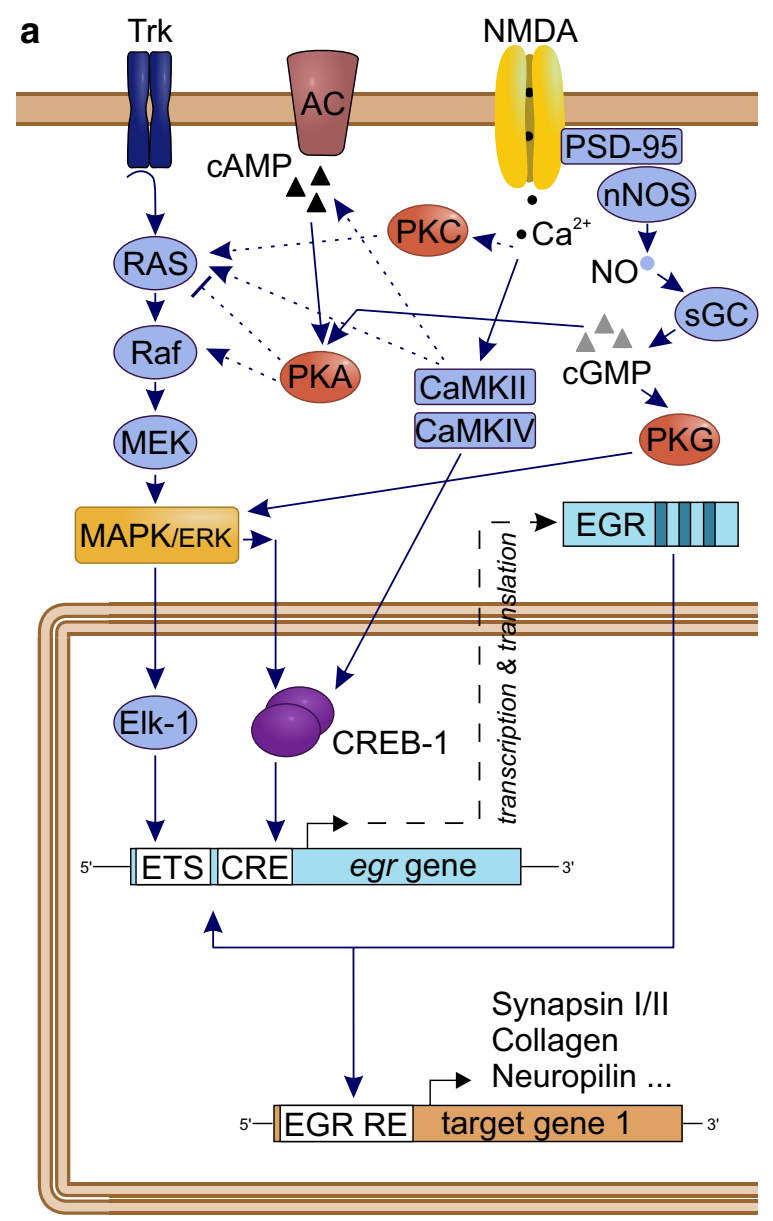

Fig. 3 Potential cellular pathways and major players for the induction of the immediate early genes $\operatorname{egr}$ (a) and $c$-jun (b), and downstream targets, with focus on pathways previously linked to learning and memory in honey bees [42, 64, 85, 158]. a Activation of tyrosine receptor kinases (Trk) by neurotrophins induces via Ras ( $G$ protein) and Raf (kinase) the MAPK/ERK pathway, resulting in an activation of the transcription factors (TF) Elk-1 and/or CREB-1. By binding to their consensus target sequences (ETS and CRE sites), the TFs induce the transcription of egr. The Egr protein product in turn functions as a TF and activates the transcription of various late-response target genes. A list of candidate downstream genes in honey bees can be found in Khamis et al. [91]. Egr additionally auto-regulates its own

the DNA-binding domain with other proteins or co-factors [118].

Egr genes were first discovered in a screening assay searching for factors determining the differentiation of embryonic rat neuroblasts into neuron-like cells [119]. Besides its activation by the neuropeptide NGF in neuroblasts, egr expression is also induced by a variety of pharmacological and physiological stimulants, including glutamate and NMDA, dopamine and cocaine, caffeine, ethanol, visual and tactile stimulation, restrainment, and learning (reviewed in [68]). The putative role of Egr in learning and memory formation is of increasing interest in vertebrate

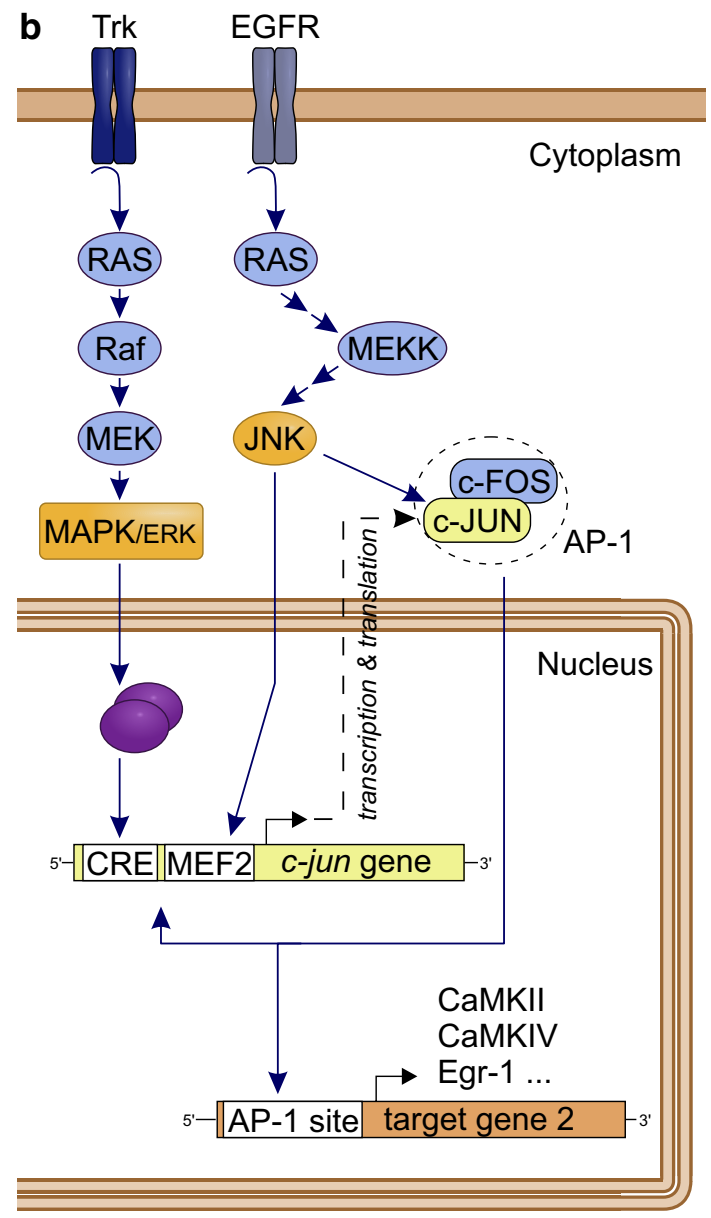

expression by interacting with the promotor of the egr gene. Alternative regulation pathways include the cAMP-PKA signaling pathway and NMDA receptor-mediated activation of PKC or CaM kinases. b Activation of $c$-jun is also mediated by the MAP/ERK pathway. Another MAPK signaling pathway includes the c-jun NH2-terminal kinase (JNK), which activates $c$-jun expression by binding of the MEF2 site in the promotor. c-Jun protein is regulated through phosphorylation by JNK and forms homo- or heterodimers (e.g., with c-Fos) resulting in the activator protein 1 (AP-1) complex, which regulates gene transcription via AP-1 binding sites on the DNA. c-Jun also auto-regulates its own transcription. Pathways compiled after $[64,112,113,135,180-182]$

neuroscience. Cerebral expression of Egr family members is induced by various learning tasks including visual associative learning (macaques [120]), spatial learning (rats [75], mice [121]), vocal communication and auditory memory formation (zebra finches [70]), as well as the formation of olfactory long-term memories (mice [122]). In all cases, the formation of new associations is required for the activation of $e g r$ genes, as sensory stimulation and motor responses alone are not sufficient to increase expression levels. Members of the Egr family are critically involved in long-term potentiation (LTP) processes, for which the activation of $e g r$ genes is required for the maintenance of late phases of LTP 
and the formation of LTM (reviewed in Refs. [112, 122, 123]). The degree to which Egr is up-regulated after learning correlates with the persistence of LTP [124].

In honey bees, only a single orthologous egr gene (named Amegr in Apis mellifera) is known, located on chromosome 15 and expressed in three distinct isoforms of unknown function $[89,96]$. Induction of Amegr mRNA expression was observed in the developing brain [89], after awakening from $\mathrm{CO}_{2}$ anesthesia $[94,95]$, in mushroom bodies after orientation flights in young foragers [95, 101], and in response to conspecific intruders [125]. In addition, foraging bees had, on average, higher Amegr levels compared to nursing bees [91], and foragers showed an increase in Amegr levels when starting to continuously visit a feeding site [102]. In contrast, exposure to isolated stimuli like a pulse of light or alarm pheromone was not sufficient to induce Amegr expression in harnessed bees [96]. By analyzing the promoter regions of differentially expressed genes between nurses and foragers, Khamis et al. [91] identified 424 genes that are potentially regulated by the Amegr protein. This underlines the wide range of functional connections of this transcription factor. So far, no direct role of Amegr expression in learning and memory processes was shown, even though its implication in orientation [101], foraging [91, 102, 103], and drone mating flights [126] strongly suggest such a function. Singh et al. [102] showed that a foraging-dependent upregulation of Amegr is associated with an activation of downstream genes involved in learning and memory. Another open question is whether the three expressed isoforms of Amegr have different functions or show brain-neuropil-specific expression patterns.

\section{c-jun (jra) and c-fos (kayak): formation of the dimeric AP-1 transcription factor complex} (Fig. 3b)

The activator protein-1 (AP-1) transcription factor is composed of homo- or heterodimers formed between Jun and Fos protein family members. Both, c-Jun and c-Fos, belong to bZIP-type DNA-binding transcription factors, which are characterized by a basic DNA-binding domain and the "Leucine zipper" dimerization domain [127, 128]. AP-1 regulates genes by binding to the DNA consensus sequence 5'-TGA G/C TCA-3', which is present in the promotor region of target genes and called TPA responsive element (TRE) or AP-1 site (reviewed in $[129,130])$. AP-1 regulates genes involved in neuronal signal transmission.

C-Jun is a highly conserved member of the Jun family, which is encoded by an intronless gene that is expressed in a single isoform, both in vertebrates and honey bees [96, 131]. The mRNA consists of one of the longest 5 ' untranslated regions known, possibly indicative of a strong posttranscriptional regulation, which is in accordance with the pronounced differences between $c$-jun mRNA and protein levels found in stimulated cells $[132,133]$. The expression of the $c$-jun gene is regulated by constitutively expressed transcription factors such as CREB and ATF, in response to various stimuli including growth factors, cytokines, and UV radiation [134]. In addition, $c$-jun is positively autoregulated by AP-1, resulting in signal amplification and signal prolongation [133, 135]. Jun proteins include a Jun domain, which can be modified by posttranslational phosphorylation, e.g., by c-Jun N-terminal kinases (JNK; [136, 137]). In honey bees, the $c$-jun gene (known as Apis mellifera Jun-related antigen, Amjra) was shown to be expressed in cell somata throughout the honey bee brain [99]. Expression of Amjra was induced in the antennal lobes (AL) after stimulation with isopentyl acetate, a component of the bees' alarm pheromone [96-98], with plant odors [97], and after light exposure [96]. In the lateral protocerebrum, mushroom bodies (MB), and optical lobes (OL), Amjra expression was increased after sucrose feeding $[99,100]$. Interestingly, the response of Amjra after stimulation seems to be globally in the entire brain and independent of the stimulus modality [96, 99].

c-fos, in turn, is expressed in two different isoforms in Drosophila and, presumably, in honey bees [132, 138]. Fos transcription is mediated by CREB, and in contrast to $c$ jun, $c$-fos is downregulated by its own protein product and the AP-1 complex [134, 139-141]. Studies in human cells revealed that while both genes get rapidly and transiently induced, high $c$-jun mRNA levels last considerably longer than $c$-fos levels [129]. In honey bees, c-Fos protein levels were increased during development and in antennallobe somata of adult bees [88]. Regulation of $c$-fos mRNA expression was analyzed for honey bees mostly in the context of immunoreaction and pesticide exposure [90, 142], as well as in mucus gland of differentially aged drones [143]. To our knowledge, no analysis of brain mRNA expression of $c-f o s$ has been done so far.

\section{Hr38 (Nr4a)}

The hormone receptor 38 (Hr38) in insects bears structural homology to the vertebrate nuclear receptor related 1 protein (NURR1, also known as NR4A). It is regulated by Egr and has been suggested to fulfil important neuronal functions by mediating ecdysteroid signaling [91, 102]. Expression of hr38 was used to monitor neuronal activation in Drosophila and moths (Bombyx mori) [53, 144]. In honey bees, foragers possess elevated $h r 38$ expression as compared to nurses and queens [145]. Only recently was $\mathrm{Hr} 38$ expression shown to be induced following seizure and orientation flights [95], during foraging behavior [102] and in the context of aggression [125]. The $h r 38$ gene is likely expressed in more than one isoform. 


\section{Other potential IEG candidates in honey bees}

The non-coding nuclear RNA kakusei was found to be induced in the densely packed inner compact Kenyon cells of the mushroom bodies by a variety of stimuli including seizure following anesthesia, during the behavioral transition from nurses to forager bees, and after reorientation in foragers $[92,93]$. Even though its function is unclear, one inducible and several constitutively expressed transcript variants were identified [93]. Additional IEG candidates were discovered by seizure induction experiments and included genes encoding protein kinases and nucleotidyltransferases [95]. However, kakusei does not appear to have any orthologous genes in other taxa, and for the other two gene groups orthologous genes are still awaiting annotation. Therefore, these genes might be currently less suitable for (comparative) functional IEG studies in social insects.

\section{Outlook and future directions}

Several studies in recent years emphasized the potential of IEGs as genomic markers for neuronal activation in social insect brains [92, 100-103]. This approach helped, for example, to identify brain regions in honey bees that are involved in the evaluation of food type and value [100] or that are active during orientation flights $[92,101]$ and foraging $[102$, 103]. Honey bees showed an increased IEG expression even in anticipation of foraging behavior, particularly in the small Kenyon cells of the mushroom bodies [103]. Kiya and Kubo [147] went one step further and demonstrated a behaviordependent IEG activation of biochemically identified neuron populations in the optic lobes by simultaneously measuring expression of kakuse $i$ and the neurotransmitter gammaAminobutyric acid (GABA) in a double-in situ hybridization assay. This approach is particularly promising as in insects most neuronal cell bodies are located in the cell body rind surrounding the neuropil mass and often cannot be associated with a specific brain region (except for the mushroom bodies). Double labeling could, therefore, help to identify neuron types and neuronal circuits based on biochemical markers.

Promising brain neuropils to study the neuron-specific expression and differential activation of IEGs in more detail are the insect mushroom bodies (MB) and the central complex (CX). MBs are brain centers for multimodal sensory integration and learning and memory, and functional correlations between the connectivity of MB synaptic microcircuits and various behaviors were found in bees [36, 148], wasps [149, 150], and ants [6, 151]. Depending on the type of stimulation, properties of the synaptic network in MBs can change: for example, sensory exposure leads to presynaptic pruning and postsynaptic sprouting [56, 152], and associative learning and long-term memory formation is correlated with presynaptic sprouting $[6,36]$. The $C X$ is involved in sensory integration and high-order motor control and was shown to express neuronal plasticity induced by complex visual learning and memory formation [151, 153-155]. The specific programs underlying plasticity in both neuropils are likely orchestrated by different sets of IEGs or, alternatively, the same IEGs expressed in different sets of neurons [103, 156]. Therefore, IEG-based approaches are applicable at two different levels: first, identification of relevant IEGs, followed by double-in situ hybridization could help to identify the type of neuron populations that are involved in the different physiological programs and types of neuroplasticity. Second, inhibition of the expression of particular IEGs should, for example, impact the level of synaptic connectivity and result in a reduced memory capacity [157]. To test the latter, IEG knockdown assays, like in vivo RNA interference (RNAi), combined with behavioral learning experiments or neuroanatomical analyses are promising. Such an approach, for example, uncovered the importance and the distribution of the activated "memory protein" CaMKII, which has a dual function both as activator and target of IEGs in long-term memory formation [158-160].

IEG studies are also promising for the identification of neurocircuits involved in processing sensory information. The use of a magnetic compass, for example, is known from various animals like birds, mammals, crustaceans, and also social insects such as ants and honey bees [161-164]. Despite the broad distribution of magnetoreception in the animal kingdom, the sensory pathways and perceptual mechanisms are mostly unexplored. In insects, a sensory mechanism and putative brain areas responsible for processing magnetic information are completely unknown, making the use of electrophysiological recording or live-imaging techniques inefficient. Screening for a magnetic-field driven induction of IEGs, for example, during learning or orientation excursions in naïve animals, might be a promising approach to identify involved neurocircuits. A similar approach could help to uncover neurobiological mechanisms that underlie the honey bee's dance communication [165]. Between dancing bee species and species that lack the ritualized dances (e.g., bumble bees), no apparent differences were found in sensory projections [166]. Adaptations in the neuronal circuitry that facilitate the specific dance behavior thus seem to be rather small and a comparative IEG expression analysis might help to identify such differences.

As IEG expression is likely in many cases highly specific regarding the stimulation paradigm and the behavioral responses [144], a systematic analysis of the role of different stimulation programs and contexts is required to specify the functional role of candidate genes. In songbirds, for example, expression of an egr homolog is significantly increased in the brain when birds hear a song of 
their own species, as compared to heterospecific songs, and decreases when the song has been made familiar by repetition [70, 71]. Therefore, known IEGs in social insects need to be tested in a larger variety of developmental stages, stimulus repetition rates or behavioral contexts as IEG expression can be highly selective for one or all of these parameters. Honey bees and bumble bees, for example, respond to the same scent marks deposited by conspecifics at food sources either by avoiding or approaching them, depending on previous foraging success on marked flowers [167]. In leaf-cutting ants of the genus Acromyrmex, the degree of allogrooming behavior as a part of the social immune response is regulated depending on previous infections of the colony [168]. Such adaptive and context-specific behaviors are potentially mediated by a differential regulation of IEGs in inhibitory or excitatory neuronal circuits. Therefore, a careful dissection of the relationship between stimulation properties and the characteristics of IEG activation is essential. In addition, one has to keep in mind that neuronal activation might occur without the induction of IEGs or that the expression of IEGs might occur independently from neuronal stimulation [169]. For example, an isolated exposure of honey bees to olfactory or visual stimuli does not induce $e g r$ expression, even though neuronal activation in this paradigm is indicated by the expression of the IEG jra [96].

To study the potential of IEG-based approaches, Pavlovian conditioning under harnessed conditions as it is now established in various bee [30,170-173] and ant species $[174,175]$ is a promising complement to experiments with free-moving animals. In such an approach, stimulus features can be gradually dissected when individuals are kept under controlled conditions [176, 177] and the brain can be accessed in vivo [38, 178]. Approaches monitoring IEG expression thus provide a unique possibility to analyze the neuronal control of naturally motivated behaviors both in natural (social) environments and under more isolated and controlled laboratory conditions.

Finally, while putative IEGs are now available for honey bees, other social insect species need to be screened for homologous genes, to broaden the field of IEG applications and the understanding of gene functions. For example, IEGbased comparative studies among different social insect species could help to unveil the neuronal correlates that facilitate the emergence of sociality. In contrast to vertebrates (social brain hypothesis), the level of sociality in insects is not reflected in simple correlations with brain (neuropil) volumes [179]. Therefore, an alternative approach to reveal general neuronal constraints underlying social systems might be the IEG-based detection of neuronal circuits involved in social tasks, the processing of social signals, such as recruitment pheromones or cuticular hydrocarbons, and the regulation of behavioral plasticity. In this context, egr-1 might be particularly useful, as it was shown to respond to social stimuli in different vertebrate species $[49,51]$.

The hitherto success and obvious benefits of IEG analyses in vertebrates and pioneering studies in honey bees should encourage more researchers in behavioral neuroscience to pursue this new approach. We, therefore, aim to advance the usage of this promising tool to other social insect species, as comparative studies are needed to uncover the mechanisms underlying their sophisticated behaviors in the social context.

Acknowledgements We thank Divya Ramesh and two anonymous reviewers for valuable comments on an earlier version of the manuscript. FMJS was supported by a grant of the German Excellence Initiative to the Graduate School of Life Sciences, University of Würzburg. $\mathrm{AB}$ was supported by NCBS-TIFR institutional funding (No. 12P4167).

Open Access This article is distributed under the terms of the Creative Commons Attribution 4.0 International License (http://creativeco mmons.org/licenses/by/4.0/), which permits unrestricted use, distribution, and reproduction in any medium, provided you give appropriate credit to the original author(s) and the source, provide a link to the Creative Commons license, and indicate if changes were made.

\section{References}

1. Wilson EO (1971) The insect societies. Harvard University Press, Cambridge

2. Gordon DM (2016) From division of labor to the collective behavior of social insects. Behav Ecol Sociobiol 70:1101-1108

3. Seeley TD (1996) The wisdom of the hive. Harvard University Press, Cambridge

4. Sheehan MJ, Tibbetts EA (2011) Specialized face learning is associated with individual recognition in paper wasps. Science 334(6060):1272-1275

5. Wehner R (2003) Desert ant navigation: how miniature brains solve complex tasks. J Comp Physiol A Neuroethol Sens Neural Behav Physiol 189(8):579-588

6. Falibene A, Roces F, Rössler W (2015) Long-term avoidance memory formation is associated with a transient increase in mushroom body synaptic complexes in leaf-cutting ants. Front Behav Neurosci 9:84

7. Srinivasan MV (2010) Honey bees as a model for vision, perception, and cognition. Annu Rev Entomol 55:267-284

8. Avargues-Weber A, Deisig N, Giurfa M (2011) Visual cognition in social insects. Annu Rev Entomol 56:423-443

9. Chittka L (2017) Bee cognition. Curr Biol 27(19):R1049-R1053

10. Giurfa M, Menzel R (2013) Cognitive components of insect behavior. In: Menzel R, Benjamin PR (eds) Handbook of behavioral neuroscience, vol 22. Elsevier, Amsterdam, pp 14-25

11. Giurfa M (2013) Cognition with few neurons: higher-order learning in insects. Trends Neurosci 36(5):285-294

12. Giurfa $M(2015)$ Learning and cognition in insects. Wiley Interdiscip Rev Cogn Sci 6(4):383-395

13. Alem S, Perry CJ, Zhu X, Loukola OJ, Ingraham T, Sovik E, Chittka L (2016) Associative mechanisms allow for social learning and cultural transmission of string pulling in an insect. PLoS Biol 14(10):e1002564 
14. Loukola OJ, Perry CJ, Coscos L, Chittka L (2017) Bumblebees show cognitive flexibility by improving on an observed complex behavior. Science 355:833-836

15. Zhang S, Schwarz S, Pahl M, Zhu H, Tautz J (2006) Honeybee memory: a honeybee knows what to do and when. J Exp Biol 209(Pt 22):4420-4428

16. Koltermann R (1974) Periodicity in the activity and learning performance of the honeybee. In: Barton Browne L (ed) Experimental analysis of insect behaviour. Springer, Berlin

17. von Frisch K (1965) Tanzsprache und Orientierung der Bienen. Springer, Berlin

18. Dacke M, Srinivasan MV (2008) Evidence for counting in insects. Anim Cogn 11(4):683-689

19. Gross HJ, Pahl M, Si A, Zhu H, Tautz J, Zhang S (2008) Number-based visual generalisation in the honeybee. PLoS One 4(1): 4263

20. Chittka L, Geiger K (1995) Can honey bees count landmarks? Anim Behav 49:159-164

21. Giurfa M (2007) Behavioral and neural analysis of associative learning in the honeybee: a taste from the magic well. J Comp Physiol A Neuroethol Sens Neural Behav Physiol 193(8):801-824

22. Menzel R, Giurfa M (2001) Cognitive architecture of a minibrain: the honeybee. Trends Cogn Sci 5(2):62-71

23. Giurfa M (2003) Cognitive neuroethology: dissecting nonelemental learning in a honeybee brain. Curr Opin Neurobiol 13(6):726-735

24. Hager FA, Kirchner WH (2013) Vibrational long-distance communication in the termites Macrotermes natalensis and Odontotermes sp. J Exp Biol 216:3249-3256

25. Trible W, Olivos-Cisneros L, McKenzie SK, Saragosti J, Chang NC, Matthews BJ, Oxley PR, Kronauer DJC (2017) Orco mutagenesis causes loss of antennal lobe glomeruli and impaired social behavior in ants. Cell 170(4):727-735 e10

26. Yan H, Opachaloemphan C, Mancini G, Yang H, Gallitto M, Mlejnek J, Leibholz A, Haight K, Ghaninia M, Huo L, Perry M, Slone J, Zhou X, Traficante M, Penick CA, Dolezal K, Gokhale K, Stevens K, Fetter-Pruneda I, Bonasio R, Zwiebel LJ, Berger SL, Liebig J, Reinberg D, Desplan C (2017) An engineered orco mutation produces aberrant social behavior and defective neural development in ants. Cell 170(4):736-747 e9

27. Zube C, Rössler W (2008) Caste- and sex-specific adaptations within the olfactory pathway in the brain of the ant Camponotus floridanus. Arthropod Struct Dev 37(6):469-479

28. Bonasio R, Zhang G, Ye C, Mutti NS, Fang X, Qin N, Donahue G, Yang P, Li Q, Li C, Zhang P, Huang Z, Berger SL, Reinberg D, Wang J, Liebig J (2010) Genomic comparison of the ants Camponotus floridanus and Harpegnathos saltator. Science 329:1068-1071

29. Tibbetts EA (2002) Visual signals of individual identity in the wasp Polistes fuscatus. Proc Biol Sci 269(1499):1423-1428

30. Lichtenstein L, Sommerlandt FMJ, Spaethe J (2015) Dumb and lazy? A comparison of color learning and memory retrieval in drones and workers of the buff-tailed bumblebee, Bombus terrestris, by means of PER conditioning. PLoS One 10(7): 0134248

31. Saleh N, Chittka L (2007) Traplining in bumblebees (Bombus impatiens): a foraging strategy's ontogeny and the importance of spatial reference memory in short-range foraging. Oecologia 151(4):719-730

32. Riveros AJ, Gronenberg W (2012) Decision-making and associative color learning in harnessed bumblebees (Bombus impatiens). Anim Cogn 15(6):1183-1193
33. Withers GS, Fahrbach SE, Robinson GE (1993) Selective neuroanatomical plasticity and division of labour in the honeybee. Nature 364:238-240

34. Groh C, Lu Z, Meinertzhagen IA, Rössler W (2012) Age-related plasticity in the synaptic ultrastructure of neurons in the mushroom body calyx of the adult honeybee Apis mellifera. J Comp Neurol 520(15):3509-3527

35. Dyer FC (1985) Mechanisms of dance orientation in the Asian honey bee Apis florea L. J Comp Physiol 157:183-198

36. Hourcade B, Muenz TS, Sandoz JC, Rössler W, Devaud JM (2010) Long-term memory leads to synaptic reorganization in the mushroom bodies: a memory trace in the insect brain? J Neurosci 30(18):6461-6465

37. Faber T, Joerges J, Menzel R (1999) Associative learning modifies neural representations of odors in the insect brain. Nat Neurosci 2(1):74-78

38. Strube-Bloss MF, Nawrot MP, Menzel R (2011) Mushroom body output neurons encode odor-reward associations. J Neurosci 31(8):3129-3140

39. Yan H, Simola DF, Bonasio R, Liebig J, Berger SL, Reinberg D (2014) Eusocial insects as emerging models for behavioural epigenetics. Nat Rev Genet 15(10):677-688

40. Maleszka J (2016) Epigenetic code and insect behavioural plasticity. Curr Opin Insect Sci 15:45-52

41. Biergans SD, Jones JC, Treiber N, Galizia CG, Szyszka P (2012) DNA methylation mediates the discriminatory power of associative long-term memory in honeybees. PLoS One 7(6):e39349

42. Eisenhardt D (2014) Molecular mechanisms underlying formation of long-term reward memories and extinction memories in the honeybee (Apis mellifera). Learn Mem 21(10):534-542

43. Mayford M, Siegelbaum SA, Kandel ER (2012) Synapses and memory storage. Cold Spring Harb Perspect Biol 4(6):a005751

44. Alberini CM (2009) Transcription factors in long-term memory and synaptic plasticity. Physiol Rev 89:121-145

45. Smid HM, Vet LE (2016) The complexity of learning, memory and neural processes in an evolutionary ecological context. Curr Opin Insect Sci 15:61-69

46. Becker N, Kucharski R, Rössler W, Maleszka R (2016) Agedependent transcriptional and epigenomic responses to light exposure in the honey bee brain. FEBS Open Bio 6(7):622-639

47. Ho VM, Lee J-A, Martin KC (2011) The cell biology of synaptic plasticity. Science 334(6056):623-628

48. Clayton DF (2000) The genomic action potential. Neurobiol Learn Mem 74(3):185-216

49. Morgan JI, Curran T (1989) Stimulus-transcription coupling in neurons: role of cellular immediate-early genes. Trends Neurosci 12(11):459-462

50. Jarvis ED, Scharff C, Grossman MR, Ramos JA, Nottebohm F (1998) For whom the bird sings: context-dependent gene expression. Neuron 21:775-788

51. Robinson GE, Fernald RD, Clayton DF (2008) Genes and social behavior. Science 322:896-900

52. Robinson GE, Grozinger CM, Whitfield CW (2005) Sociogenomics: social life in molecular terms. Nat Rev Genet 6(4):257-270

53. Fujita N, Nagata Y, Nishiuchi T, Sato M, Iwami M, Kiya T (2013) Visualization of neural activity in insect brains using a conserved immediate early gene, Hr38. Curr Biol 23(20):2063-2070

54. Crow D (2017) Biology gone wild. Cell 170(2):219-221

55. Stieb SM, Muenz TS, Wehner R, Rössler W (2010) Visual experience and age affect synaptic organization in the mushroom bodies of the desert ant Cataglyphis fortis. Dev Neurobiol 70(6):408-423

56. Scholl C, Wang Y, Krischke M, Mueller MJ, Amdam GV, Rössler W (2014) Light exposure leads to reorganization 
of microglomeruli in the mushroom bodies and influences juvenile hormone levels in the honeybee. Dev Neurobiol 74(11):1141-1153

57. Yilmaz A, Lindenberg A, Albert S, Grübel K, Spaethe J, Rössler W, Groh C (2016) Age-related and light-induced plasticity in opsin gene expression and in primary and secondary visual centers of the nectar-feeding ant Camponotus rufipes. Dev Neurobiol 76(9):1041-1057

58. Molina Y, Harris RM, O'Donnell S (2009) Brain organization mirrors caste differences, colony founding and nest architecture in paper wasps (Hymenoptera: Vespidae). Proc Biol Sci 276(1671):3345-3351

59. Okada R, Rybak J, Manz G, Menzel R (2007) Learning-related plasticity in PE1 and other mushroom body-extrinsic neurons in the honeybee brain. J Neurosci 27(43):11736-11747

60. Sheng M, Greenberg ME (1990) The regulation and function of $c-f o s$ and other immediate early genes in the nervous system. Neuron 4:477-485

61. Finkbeiner S, Greenberg ME (1998) $\mathrm{Ca}^{2+}$ channel-regulated neuronal gene expression. Dev Neurobiol 37(1):171-189

62. Perez-Cadahia B, Drobic B, Davie JR (2011) Activation and function of immediate-early genes in the nervous system. Biochem Cell Biol 89(1):61-73

63. Hughes P, Dragunow M (1995) Induction of immediate-early genes and the control of neurotransmitter-regulated gene expression within the nervous system. Pharmacol Rev 47(1):133-178

64. Müller U (2013) The molecular biology of learning and memory-memory phases and signaling cascades. In: Galizia CG, Eisenhardt D, Giurfa M (eds) Honeybee neurobiology and behavior. Springer Science, Heidelberg, pp 409-422

65. Tischmeyer W, Grimm R (1999) Activation of immediate early genes and memory formation. Cell Mol Life Sci 55:564-574

66. Terleph TA, Tremere LA (2006) The use of immediate early genes as mapping tools for neuronal activation: concepts and methods. In: Pinaud R, Tremere LA (eds) Immediate early genes in sensory processing, cognitive performance and neuroloical disorders. Springer Science + Business Media, New York, pp $1-10$

67. Morgan JI, Curran T (1991) Stimulus-transcription coupling in the nervous system: involvement of the inducible proto-oncogenes fos and jun. Annu Rev Neurosci 14:421-451

68. Beckmann AM, Wilce PA (1997) EGR transcription factors in the nervous system. Neurochem Int 31(4):477-510

69. Herdegen T, Leah JD (1998) Inducible and constitutive transcription factors in the mammalian nervous system: control of gene expression by Jun, Fos and Krox, and CREB/ATF proteins. Brain Res Rev 28:370-490

70. Mello CV, Ribeiro S (1998) ZENK protein regulation by song in the brain of songbirds. J Comp Neurol 393:426-438

71. Mello CV, Clayton DF (1994) Song-induced ZENK gene expression in auditory pathways of songbird brain and its relation to the song control system. J Neurosci 14(11):6652-6656

72. Bisler S, Schleicher A, Gass P, Stehle JH, Zilles K, Staiger JF (2002) Expression of c-Fos, ICER, Krox-24 and JunB in the whisker-to-barrel pathway of rats: time course of induction upon whisker stimulation by tactile exploration of an enriched environment. J Chem Neuroanatomy 23:187-198

73. Herdegen T, Kovary K, Leah JD, Bravo R (1991) Specific temporal and spatial distribution of JUN, FOS and KROX-24 proteins in spinal neurons following noxious transsynaptic stimulation. J Comp Neurol 313:178-191

74. Morgan JI, Cohen DR, Hempstead JL, Curran T (1987) Mapping patterns of $c$-fos expression in the central nervous system after seizure. Science 237(4811):192-197

75. Guzowski JF, Setlow B, Wagner EK, McGaugh JL (2001) Experience-dependent gene expression in the rat hippocampus after spatial learning: a comparison of the immediate-early genes arc, c-fos, and zif268. J Neurosci 21(14):5089-5098

76. Vazdarjanova A, McNaughton BL, Barnes CA, Worley PF, Guzowski JF (2002) Experience-dependent coincident expression of the effector immediate-early genes arc and homer $1 a$ in hippocampal and neocortical neuronal networks. J Neurosci 22(23):10067-10071

77. Mello CV, Vicario DS, Clayton DF (1992) Song presentation induces gene expression in the songbird forebrain. Proc Natl Acad Sci USA 89:6818-6822

78. Harlan RE, Garcia MM (1998) Drugs of abuse and immediateearly genes in the forebrain. Mol Neurobiol 16:221-267

79. Guzowski JF, McNaughton BL, Barnes CA, Worley PF (1999) Environment-specific expression of the immediate-early gene $A r c$ in hippocampal neuronal ensembles. Nat Neurosci 2(12):1120-1124

80. Pearson AG, Byrne UT, MacGibbon GA, Faull RL, Dragunow M (2006) Activated c-Jun is present in neurofibrillary tangles in Alzheimer's disease brains. Neurosci Lett 398(3):246-250

81. Migheli A, Piva R, Atzori C, Troost D, Schiffer D (1997) $\mathrm{c}-J u n, J N K / S A P K$ kinases and transcription factor NF- $\kappa B$ are selectively activated in astrocytes, but not motor neurons, in amyotrophic lateral sclerosis. J Neuropathol Exp Neurol 56(12):1314-1322

82. Lee H, Kim DW, Remedios R, Anthony TE, Chang A, Madisen L, Zeng H, Anderson DJ (2014) Scalable control of mounting and attack by Esr1+ neurons in the ventromedial hypothalamus. Nature 509(7502):627-632

83. Klein B, Bautze V, Maier AM, Deussing J, Breer H, Strotmann J (2015) Activation of the mouse odorant receptor 37 subsystem coincides with a reduction of novel environment-induced activity within the paraventricular nucleus of the hypothalamus. Eur J Neurosci 41(6):793-801

84. Müller U (2002) Learning in honeybees: from molecules to behaviour. Zoology 105:313-320

85. Menzel R (2012) The honeybee as a model for understanding the basis of cognition. Nat Rev Neurosci 13(11):758-768

86. Consortium THGS (2006) Insights into social insects from the genome of the honeybee Apis mellifera. Nature 443:931-949

87. Zayed A, Robinson GE (2012) Understanding the relationship between brain gene expression and social behavior: lessons from the honey bee. Annu Rev Genet 46:591-615

88. Fonta C, Gascuel J, Masson C (1995) Brain FOS-like expression in developing and adult honeybees. NeuroReport 6:745-749

89. Ugajin A, Watanabe T, Uchiyama H, Sasaki T, Yajima S, Ono M (2016) Expression analysis of Egr-1 ortholog in metamorphic brain of honeybee (Apis mellifera L.): possible evolutionary conservation of roles of Egr in eye development in vertebrates and insects. Biochem Biophys Res Commun 478(2):1014-1019

90. Cizelj I, Glavan G, Bozic J, Oven I, Mrak V, Narat M (2016) Prochloraz and coumaphos induce different gene expression patterns in three developmental stages of the Carniolan honey bee (Apis mellifera carnica Pollmann). Pestic Biochem Physiol 128:68-75

91. Khamis AM, Hamilton AR, Medvedeva YA, Alam T, Alam I, Essack M, Umylny B, Jankovic BR, Naeger NL, Suzuki M, Harbers M, Robinson GE, Bajic VB (2015) Insights into the transcriptional architecture of behavioral plasticity in the honey bee Apis mellifera. Sci Rep 5:11136

92. Kiya T, Kunieda T, Kubo T (2007) Increased neural activity of a mushroom body neuron subtype in the brains of forager honeybees. PLoS One 2(4):e371

93. Kiya T, Kunieda T, Kubo T (2008) Inducible- and constitutivetype transcript variants of kakusei, a novel non-coding immediate early gene, in the honeybee brain. Insect Mol Biol 17(5):531-536 
94. Ugajin A, Kunieda T, Kubo T (2013) Identification and characterization of an Egr ortholog as a neural immediate early gene in the European honeybee (Apis mellifera L.). FEBS Lett 587(19):3224-3230

95. Ugajin A, Uchiyama H, Miyata T, Sasaki T, Yajima S, Ono M (2017) Identification and initial characterization of novel neural immediate early genes possibly differentially contributing to foraging-related learning and memory processes in the honeybee. Insect Mol Biol 27(2):154-165

96. Sommerlandt FMJ, Rössler W, Spaethe J (2017) Impact of light and alarm pheromone on immediate early gene expression in the European honeybee, Apis mellifera. Entomol Sci 20(1):122-126

97. Alaux C, Robinson GE (2007) Alarm pheromone induces immediate-early gene expression and slow behavioral response in honey bees. J Chem Ecol 33(7):1346-1350

98. Alaux C, Sinha S, Hasadsri L, Hunt GJ, Guzman-Novoa E, DeGrandi-Hoffman G, Uribe-Rubio JL, Southey BR, RodriguezZas S, Robinson GE (2009) Honey bee aggression supports a link between gene regulation and behavioral evolution. Proc Natl Acad Sci USA 106(36):15400-15405

99. McNeill MS, Robinson GE (2015) Voxel-based analysis of the immediate early gene, $c$-jun, in the honey bee brain after a sucrose stimulus. Insect Mol Biol 24(3):377-390

100. McNeill MS, Kapheim KM, Brockmann A, McGill TA, Robinson GE (2016) Brain regions and molecular pathways responding to food reward type and value in honey bees. Genes Brain Behav 15(3):305-317

101. Lutz CC, Robinson GE (2013) Activity-dependent gene expression in honey bee mushroom bodies in response to orientation flight. J Exp Biol 216(11):2031-2038

102. Singh A, Shah A, Brockmann A (2017) Honey bee foraging induces upregulation of early growth response protein 1 , hormone receptor 38 and candidate downstream genes of the ecdysteroid signalling pathway. Insect Mol Biol 27(1):90-98

103. Shah A, Jain R, Brockmann A (2018) Egr-1: a candidate transcription factor involved in molecular processes underlying timememory. Front Psychol 9:865

104. Reaume J, Sokolowski MB (2011) Conservation of gene function in behavior. Philos Trans R Soc Biol 366:2100-2110

105. Cheatle Jarvela AM, Hinman VF (2015) Evolution of transcription factor function as a mechanism for changing metazoan developmental gene regulatory networks. EvoDevo 6(3):1-11

106. Burmeister SS, Fernald RD (2005) Evolutionary conservation of the Egr-1 immediate-early gene response in a teleost. J Comp Neurol 481:220-232

107. Long KD, Salbaum JM (1998) Evolutionary conservation of the immediate-early gene ZENK. Mol Biol Evol 15(3):284-292

108. Cyriac A, Holmes G, Lass J, Belchenko D, Calin-Jageman RJ, Calin-Jageman IE (2013) An Aplysia Egr homolog is rapidly and persistently regulated by long-term sensitization training. Neurobiol Learn Mem 102:43-51

109. Conte C, Herdegen S, Kamal S, Patel J, Patel U, Perez L, Rivota M, Calin-Jageman RJ, Calin-Jageman IE (2017) Transcriptional correlates of memory maintenance following long-term sensitization of Aplysia californica. Learn Mem 24(10):502-515

110. Cao X, Koski RA, Gashler A, McKiernan M, Morris CF, Gaffney R, Hay RV, Sukhatme VP (1990) Identification and characterization of the Egr-1 gene product, a DNA-binding zinc finger protein induced by differentiation and growth signals. Mol Cell Biol 10(5):1931-1939

111. O'Donovan KJ, Tourtellotte WG, Milbrandt J, Baraban JM (1999) The EGR family of transcription-regulatory factors: progress at the interface of molecular and systems neuroscience. Trends Neurosci 22(4):167-173
112. Davis S, Bozon B, Laroche S (2003) How necessary is the activation of the immediate early gene zif 268 in synaptic plasticity and learning? Behav Brain Res 142(1-2):17-30

113. Thiel G, Schoch S, Petersohn D (1994) Regulation of synapsin I gene expression by the zinc finger transcription factor zif268/ egr. J Biol Chem 269(21):1529-15301

114. Petersohn D, Schoch S, Brinkmann DR, Thiel G (1995) The human synapsin II gene promotor. J Biol Chem 270(41):24361-24369

115. Li Y, Camp S, Rachinsky TL, Bongiorno C, Taylor P (1993) Promotor elements and transcriptional control of the mouse acetylcholinesterase gene. J Biol Chem 268(5):3563-3572

116. Mayer SI, Willars GB, Nishida E, Thiel G (2008) Elk-1, CREB, and MKP-1 regulate Egr-1 expression in gonadotropinreleasing hormone stimulated gonadotrophs. J Cell Biochem 105(5): 1267-1278

117. Cao X, Mahendran R, Guy GR, Tan YH (1993) Detection and characterization of cellular EGR-1 binding to its recognition site. J Biol Chem 268(23):16949-16957

118. Poirier R, Cheval H, Mailhes C, Garel S, Charnay P, Davis S, Laroche S (2008) Distinct functions of Egr gene family members in cognitive processes. Front Neurosci 2(1):47-55

119. Milbrandt J (1987) A nerve growth factor-induced gene encodes a possible transcriptional regulatory factor. Science 238(4828):797-799

120. Okuno H, Miyashita Y (1996) Expression of the transcription factor Zif268 in the temporal cortex of monkeys during visual paired associate learning. Eur J Neurosci 8:2118-2128

121. Fordyce DE, Bhat RV, Baraban JM, Wehner JM (1994) Genetic and activity-dependent regulation of zif268 expression: association with spatial learning. Hippocampus 4(5):559-568

122. Jones MW, Errington ML, French PJ, Fine A, Bliss TVP, Garel S, Charnay P, Bozon B, Laroche S, Davis S (2001) A requirement for the immediate early gene Zif268 in the expression of late LTP and long-term memories. Nat Neurosci 4(3):289-296

123. Cole AJ, Saffen DW, Baraban JM, Worley PF (1989) Rapid increase of an immediate early gene messenger RNA in hippocampal neurons by synaptic NMDA receptor activation. Nature 340:474-476

124. Abraham WC, Mason SE, Demmer J, Williams JM, Richardson CL, Tate WP, Lawlor PA, Dragunow M (1993) Correlations between immediate early gene induction and the persistence of long-term potentiation. Neuroscience 56(3):717-727

125. Shpigler HY, Saul MC, Murdoch EE, Cash-Ahmed AC, Seward $\mathrm{CH}$, Sloofman L, Chandrasekaran S, Sinha S, Stubbs LJ, Robinson GE (2017) Behavioral, transcriptomic and epigenetic responses to social challenge in honey bees. Genes Brain Behav 16(6):579-591

126. Naeger NL, Robinson GE (2016) Transcriptomic analysis of instinctive and learned reward-related behaviors in honey bees. J Exp Biol 219(Pt 22):3554-3561

127. Kouzarides T, Ziff E (1998) The role of the leucine zipper in the fos-jun interaction. Nature 336:646-651

128. Landschulz WH, Johnson PF, McKnight SL (1988) The leucine zipper: a hypothetical structure common to a new class of DNA binding proteins. Science 240(4860):1759-1764

129. Angel P, Karin M (1991) The role of Jun, Fos and the AP-1 complex in cell-proliferation and transformation. Biochem Biophys Acta 1072:129-157

130. Bahrami S, Drablos F (2016) Gene regulation in the immediate-early response process. Adv Biol Regul 62:37-49

131. Mechta-Grigoriou F, Gerald D, Yaniv M (2001) The mammalian Jun proteins: redundancy and specificity. Oncogene 20:2378-2389 
132. Hattori K, Angel P, Le Beau MM, Karin M (1988) Structure and chromosomal localization of the functional intronless human JUN protooncogene. PNAS 85:9148-9152

133. Angel P, Hattori K, Smeal T, Karin M (1988) The jun protooncogene is positively autoregulated by its product, Jun/AP-1. Cell 55:875-885

134. Karin M, Liu Z, Zandi E (1997) AP-1 function and regulation. Curr Opin Cell Biol 9:240-246

135. Clarke N, Arenzana N, Hai T, Minden A, Prywes R (1998) Epidermal growth factor induction of the c-jun promoter by a Rac pathway. Mol Cell Biol 18(2):1065-1073

136. Minden A, Lin A, Smeal T, Dérijard B, Cobb M, Davis R, Karin M (1994) c-Jun N-terminal phosphorylation correlates with activation of the JNK subgroup but not the ERK subgroup of mitogen-activated protein kinases. Mol Cell Biol 14(10):6683-6688

137. Kallunki T, Deng T, Hibi M, Karin M (1996) c-Jun can recruit JNK to phosphorylate dimerization partners via specific docking interactions. Cell 87:929-939

138. Souid S, Yanicostas C (2003) Differential expression of the two Drosophila fos/kayak transcripts during oogenesis and embryogenesis. Dev Dyn 227(1):150-154

139. Schönthal A, Büscher M, Angel P, Rahmsdorf HJ, Ponta H, Hattori K, Chiu R, Karin M, Herrlich P (1989) The Fos and Jun/AP-1 proteins are involved in the downregulation of Fos transcription. Oncogene 4(5):629-636

140. Sassone-Corsi P, Sisson JC, Verma IM (1988) Transcriptional autoregulation of the proto-oncogene fos. Nature 334-319:314

141. Sheng M, McFadden G, Greenberg ME (1990) Membrane depolarization and calcium induce $c$-fos transcription via phosphorylation of transcription factor CREB. Neuron 4:571-582

142. Richard F-J, Holt HL, Grozinger CM (2012) Effects of immunostimulation on social behavior, chemical communication and genome-wide gene expression in honey bee workers (Apis mellifera). BMC Genom 13:558

143. Colonello-Frattini NA, Hartfelder K (2009) Differential gene expression profiling in mucus glands of honey bee (Apis mellifera) drones during sexual maturation. Apidologie 40(4):481-495

144. Chen X, Rahman R, Guo F, Rosbash M (2016) Genome-wide identification of neuronal activity-regulated genes in Drosophila. Elife 5:e19942

145. Yamazaki Y, Shirai K, Paul RK, Fujiyuki T, Wakamoto A, Takeuchi H, Kubo T (2006) Differential expression of HR38 in the mushroom bodies of the honeybee brain depends on the caste and division of labor. FEBS Lett 580(11):2667-2670

146. Ugajin A, Kiya T, Kunieda T, Ono M, Yoshida T, Kubo T (2012) Detection of neural activity in the brains of Japanese honeybee workers during the formation of a "hot defensive bee ball". PLoS One 7(3):e32902

147. Kiya T, Kubo T (2010) Analysis of GABAergic and non-GABAergic neuron activity in the optic lobes of the forager and re-orienting worker honeybee (Apis mellifera L). PLoS One 5(1):e8833

148. Sommerlandt FMJ, Spaethe J, Rössler W, Dyer AG (2016) Does fine color discrimination learning in free-flying honeybees change mushroom-body calyx neuroarchitecture? PLoS One 11(10):e0164386

149. O'Donnell S, Donlan N, Jones T (2007) Developmental and dominance-associated differences in mushroom body structure in the paper wasp Mischocyttarus mastigophorus. J Neurobiol 67(1):39-46

150. Jones TA, Donlan NA, O'Donnell S (2009) Growth and pruning of mushroom body Kenyon cell dendrites during worker behavioral development in the paper wasp, Polybia aequatorialis (Hymenoptera: Vespidae). Neurobiol Learn Mem 92(4):485-495
151. Grob R, Fleischmann PN, Grübel K, Wehner R, Rössler W (2017) The role of celestial compass information in Cataglyphis ants during learning walks and for neuroplasticity in the central complex and mushroom bodies. Front Behav Neurosci 11:226

152. Stieb SM, Hellwig A, Wehner R, Rössler W (2012) Visual experience affects both behavioral and neuronal aspects in the individual life history of the desert ant Cataglyphis fortis. Dev Neurobiol 72(5):729-742

153. Heinze $S$ (2017) Unraveling the neural basis of insect navigation. Curr Opin Insect Sci 24:58-67

154. Pfeiffer K, Homberg U (2014) Organization and functional roles of the central complex in the insect brain. Annu Rev Entomol 59:165-184

155. Plath JA, Entler BV, Kirkerud NH, Schlegel U, Galizia CG, Barron AB (2017) Different roles for honey bee mushroom bodies and central complex in visual learning of colored lights in an aversive conditioning assay. Front Behav Neurosci 11:98

156. Minatohara K, Akiyoshi M, Okuno H (2015) Role of immediate-early genes in synaptic plasticity and neuronal ensembles underlying the memory trace. Front Mol Neurosci 8:78

157. Lefer D, Perisse E, Hourcade B, Sandoz J, Devaud JM (2012) Two waves of transcription are required for long-term memory in the honeybee. Learn Mem 20(1):29-33

158. Scholl C, Kubert N, Muenz TS, Rössler W (2015) CaMKII knockdown affects both early and late phases of olfactory long-term memory in the honeybee. J Exp Biol 218(Pt 23):3788-3796

159. Sanhueza M, Lisman J (2013) The CaMKII/NMDAR complex as a molecular memory. Mol Brain 6(10):1-8

160. Pasch E, Münz T, Rössler W (2011) CaMKII is differentially localized in synaptic regions of Kenyon cells within the mushroom bodies of the honeybee brain. J Comp Neurol 519(18):3700-3712

161. Wiltschko W, Wiltschko R (2005) Magnetic orientation and magnetoreception in birds and other animals. J Comp Physiol A Neuroethol Sens Neural Behav Physiol 191(8):675-693

162. Buehlmann C, Hansson B, Knaden M (2012) Desert ants learn vibration and magnetic landmarks. PLoS One 7(3):e33117

163. Walker MM, Bitterman ME (1986) Conditioned responding to magnetic fields by honeybees. J Comp Physiol 157:67-71

164. Fleischmann PN, Grob R, Muller VL, Wehner R, Rössler W (2018) The geomagnetic field is a compass cue in Cataglyphis ant navigation. Curr Biol 28(9):1440-1444 e2

165. Kiya T, Kuno T (2011) Dance tape and flight parameters are associated with different mushroom body neural activities in worker honeybee brains. PLoS One 6(4):e19301

166. Brockmann A, Robinson GE (2007) Central projections of sensory systems involved in honey bee dance language communication. Brain Behav Evol 70:125-136

167. Saleh N, Chittka L (2016) The importance of experience in the interpretation of conspecific chemical signals. Behav Ecol Sociobiol 61(2):215-220

168. Walker TN, Hughes WHO (2009) Adaptive social immunity in leaf-cutting ants. Biol Lett 5:446-448

169. Kovács KJ (2008) Measurement of immediate-early gene activation-c-fos and beyond. J Neuroendocrinol 20:665-672

170. Kuwabara M (1957) Bildung des bedingten Reflexes von Pavlovs Typus bei der Honigbiene Apis mellifera. J Fac Sci Hokkaido Univ Ser VI Zool 13:458-464

171. Bitterman ME, Menzel R, Fietz A, Schäfer S (1983) Classical conditioning of proboscis extension in honeybees (Apis mellifera). J Comp Psychol 97(2):107-119

172. Wang Z, Tan K (2014) Comparative analysis of olfactory learning of Apis cerana and Apis mellifera. Apidologie 45(1):45-52 
173. Sommerlandt FMJ, Rössler W, Spaethe J (2014) Elemental and non-elemental olfactory learning using PER conditioning in the bumblebee, Bombus terrestris. Apidologie 45:106-115

174. Fernandes ASD, Buckley CL, Niven JE (2018) Visual associative learning in wood ants. J Exp Biol 221(Pt 3):jeb173260

175. Guerrieri FJ, d'Ettorre P (2010) Associative learning in ants: conditioning of the maxilla-labium extension response in $\mathrm{Cam}$ ponotus aethiops. J Insect Physiol 56(1):88-92

176. Giurfa M, Sandoz JC (2012) Invertebrate learning and memory: fifty years of olfactory conditioning of the proboscis extension response in honeybees. Learn Mem 19(2):54-66

177. Matsumoto Y, Menzel R, Sandoz J-C, Giurfa M (2012) Revisiting olfactory classical conditioning of the proboscis extension response in honey bees: a step toward standardized procedures. J Neurosci Methods 211(1):159-167

178. Haehnel M, Froese A, Menzel R (2009) In vivo $\mathrm{Ca}^{2+}$ imaging of mushroom body neurons during olfactory learning in the honey bee. J Vis Exp 30:1353
179. Lihoreau M, Latty T, Chittka L (2012) An exploration of the social brain hypothesis in insects. Front Physiol 3:442

180. Knapska E, Kaczmarek L (2004) A gene for neuronal plasticity in the mammalian brain: Zif268/Egr-1/NGFI-A/Krox-24/TIS8/ ZENK? Prog Neurobiol 74(4):183-211

181. Lopez-Bergami P, Huang C, Goydos JS, Yip D, Bar-Eli M, Herlyn M, Smalley KSM, Mahale A, Eroshkin A, Aaronson S, Ronai Z (2007) Re-wired ERK-JNK signaling pathways in melanoma. Cancer Cell 11(5):447-460

182. Gallo EF, Iadecola C (2011) Neuronal nitric oxide contributes to neuroplasticity-associated protein expression through cGMP, protein kinase $\mathrm{G}$, and extracellular signal-regulated kinase. J Neurosci 31(19):6947-6955 